\title{
Prevalence and herd-level risk factors for bovine tuberculosis in the State of Paraná, Brazil
}

\section{Prevalência e fatores de risco da tuberculose bovina no Estado do Paraná, Brasil}

\author{
Maria do Carmo Pessôa Silva ${ }^{1}$; Vitor Salvador Picão Gonçalves ${ }^{2 *}$; \\ Ana Lourdes Arrais de Alencar Mota ${ }^{3}$; Mariza Koloda ${ }^{1}$; José Soares Ferreira Neto \\ José Henrique Hildebrand Grisi-Filho ${ }^{4}$; Ricardo Augusto Dias ${ }^{4}$; Marcos Amaku; \\ Evelise Oliveira Telles ${ }^{4}$; Fernando Ferreira ${ }^{4}$; Marcos Bryan Heinemann ${ }^{4}$; \\ Amauri Alcindo Alfieri ${ }^{5}$; Ernst Eckehardt Muller ${ }^{5}$
}

\begin{abstract}
Bovine tuberculosis is a zoonosis with worldwide distribution. Its control has a direct impact on public health and livestock production. This study estimated the prevalence of infected herds and adult bovines and evaluated risk factors associated with the presence of tuberculosis within herds in the state of Paraná. The state was divided in seven livestock regions and independent sampling was performed. A total of 1,419 farms were sampled and 16,045 animals were tested using the intradermal comparative cervical tuberculin diagnostic test. The apparent and estimated prevalence rates in farms and adult bovine animals were $2.15 \%$ (95\% CI: $1.31-3.00)$ and $0.42 \%$ (95\% CI: 0.04-0.81), respectively. It was not possible to state with $95 \%$ confidence that the disease prevalence in any region was significantly different from that in other regions. There were no positive animals in the western region, and the prevalence of positive herds and animals in the other regions ranged from $1.03 \%$ to $3.89 \%$ and $0.17 \%$ to $1.08 \%$, respectively. The logistic regression model identified larger herd size $(\mathrm{OR}=2.4)$ and mechanical milking $(\mathrm{OR}=5.18)$ as risk factors associated with the presence of bovine tuberculosis. The combination of low prevalence with risk factors associated to larger herds and more intensive dairy farming, renders the state of Paraná a good candidate for the implementation of industry-based free-herd accreditation schemes and makes a case for planning risk-based surveillance targeted at major dairy basins.
\end{abstract}

Key words: Mycobacterium bovis. Paraná. Prevalence. Risk factors.

\section{Resumo}

A tuberculose bovina é uma zoonose de ampla distribuição geográfica no mundo e seu controle tem impacto direto na saúde pública e na produção pecuária. Neste trabalho, estimou-se a prevalência aparente

\footnotetext{
${ }^{1}$ Médicas Veterinárias, Agência de Defesa Agropecuária do Paraná, ADAPAR. Divisão de Defesa Agropecuária, Gerência de Saúde Animal, Curitiba, Paraná, Brasil. E-mail mcpessoasilva@gmail.com; mkoloda@adapar.pr.gov.br

2 Prof., Faculdade de Agronomia e Medicina Veterinária, Universidade de Brasília, UnB, Brasília, Brasil. E-mail: vitorspg@unb.br

${ }^{3}$ Médica Veterinária, Doutora em Saúde Animal, Faculdade de Agronomia e Medicina Veterinária, Universidade de Brasília, UnB, Brasília, DF, Brasil. E-mail: analourdes@unb.br

${ }^{4}$ Profs., Faculdade de Medicina Veterinária e Zootecnia, Universidade de São Paulo, USP, São Paulo, SP, Brasil. E-mail Brasil. E-mail jsoares@vps.fmvz.usp.br; grisi@vps.fmvz.usp.br; dias@vps.fmvz.usp.br; amaku@vps.fmvz.usp.br; evelise@vps.fmvz. usp.br; fernando@vps.fmvz.usp.br; marcosbryan@usp.br;

${ }_{5}^{5}$ Profs., Departamento de Medicina Veterinária Preventiva, Universidade Estadual de Londrina, UEL, Londrina, PR, Brasil. E-mail: alfieri@uel.br; muller@uel.br

* Author for correspondence
} 
de rebanhos e de bovinos adultos infectados, assim como os fatores de risco associados à presença da tuberculose nos rebanhos do estado do Paraná. O estado foi dividido em sete regiões pecuárias para amostragem independente. No total foram amostradas 1.419 propriedades e testados 16.045 animais. A prova diagnóstica utilizada foi a tuberculinização intradérmica cervical comparada. A prevalência aparente em propriedades e em bovinos adultos no estado do Paraná foi estimada em 2,15\% [IC 95\%: 1,31-3,00] e 0,42\% [IC 95\%: 0,04-0,81], respectivamente. Em relação às prevalências estimadas por região do estado, foram observadas heterogeneidades, não foi possível afirmar com $95 \%$ de confiança que alguma região se destacou das demais em relação à presença da tuberculose bovina. A região Oeste não apresentou animais positivos na amostra e nas demais regiões as prevalências de rebanho e animais variaram entre $1,03 \%$ - 3,89\% e $0,17 \%$ - 1,08\%, respectivamente. O modelo de regressão logística múltipla identificou como fatores de risco associados à presença de tuberculose bovina, o aumento do tamanho de rebanho $(\mathrm{OR}=2.4)$ e a existência de ordenha mecanizada na propriedade $(\mathrm{OR}=5.18)$. Assim, os resultados demonstraram que a tuberculose bovina tem prevalência baixa na maioria das regiões do Estado do Paraná e sugerem que o risco da presença da infecção aumenta em rebanhos maiores e nas propriedades leiteiras com maior grau de tecnificação. Estes resultados permitem sugerir que o Paraná está em boas condições para introduzir sistemas de vigilância baseados em risco e para implementar programas de certificação de rebanhos livres, associados às indústrias de laticínios.

Palavras-chave: Mycobacterium bovis. Paraná. Prevalência. Fatores de risco.

\section{Introduction}

The state of Paraná is located in the South of Brazil and has a geographical area of $199,282 \mathrm{~km}^{2}$, which corresponds to $2.3 \%$ of the national territory. It is subdivided into 399 municipalities and is in a transitional area in terms of its physical and natural characteristics, with different climates and soils, geographical features, geology and vegetation coverage. These factors are reflected in the diversity of livestock production systems. In regions closer to the Tropic of Capricorn (north-west and northcentral), a tropical climate predominates, sustaining beef cattle production based on zebu and crossbreeds. Temperate regions cover about two-thirds of the state; beef cattle production in these areas relies on crossbred and pure European breeds and is almost always integrated with crop production. To the south of the state, the land ownership pattern is smaller and divided into subsistence farms as well as some that specialize in dairy production (FAEP, 2010).

The cattle herd in the state of Paraná comprises approximately 9.5 million animals raised on 215,392 rural farms (PARANÁ, 2012). Dairy farming includes small scale herds with specialized breeds, which depend on family labour. Among beef herds, zebu cattle predominates, particularly the Nelore breed, which are bred in extensive systems with complete production cycles carried out on larger farms. Smaller farms generally focus on the fattening phases and beef or dairy production (FAEP, 2010).

Tuberculosis has a major impact on dairy farming and the potential for zoonotic transmission poses a risk to public health (MAPA, 2006). In 2001, the Ministry of Agriculture, Livestock and Supply of Brazil (MAPA), instituted the National Program for the Control and Eradication of Brucellosis and Animal Tuberculosis (PNCEBT). Because of the scarcity of epidemiological information, since the majority of the studies on the prevalence of bovine tuberculosis in Brazil cover small administrative units, such as state regions or municipalities (LAENDER, 1978; CASTRO, 1979; ALFINITO; OLIVEIRA, 1986; LILENBAUM et al., 1998; BELCHIOR et al., 2016; RIBEIRO et al., 2016; POLETTO et al., 2004; BRASIL, 2006; OLIVEIRA et al., 2007), MAPA has encouraged state veterinary administrations to perform state-wide studies to characterize the epidemiological status of bovine tuberculosis.

Studies conducted in 12 Federative Units revealed that herd prevalence of bovine tuberculosis varied 
between $0.36 \%$ in the Federal District, and 9.0\% in São Paulo (BAHIENSE et al., 2016; BARBIERI et al., 2016; DIAS et al., 2016; GALVIS et al., 2016; GUEDES et al., 2016; LIMA et al., 2016; NÉSPOLI et al., 2016; QUEIROZ et al., 2016; RIBEIRO et al., 2016; ROCHA et al., 2016; BAUMGARTEN et al., 2016; VENDRAME et al., 2016).

In this context, the present study aimed to (1) estimate the prevalence of tuberculosis in cattle herds and adult bovine females, and (2) identify characteristics of the production systems and animal husbandry that may be associated with increased risk of bovine tuberculosis in the state of Paraná.

\section{Material and Methods}

This study was conducted in cooperation with Ministry of Agriculture, Livestock and Food Supply (MAPA), the Laboratory of Epidemiology and Biostatistics of the University of São Paulo (LEB/ VPS/FMVZ/USP), the Veterinary Epidemiology Laboratory of the University of Brasilia (EpiPlan/ FAV/UnB) and the Animal Health Protection Agency of the State of Paraná (ADAPAR). Field work was carried out between November 2005 and August 2007 by trained veterinarians from ADAPAR, who georeferenced the sampled farms, performed diagnostic testing for bovine tuberculosis in randomly selected animals, and administered epidemiological questionnaires to the individuals responsible for each herd.

The study was a cross-sectional random survey. The state of Paraná was divided in seven geographic areas (Figure 1), also called productive regions, based on differences in climate, production systems, herd structure size, and types of livestock production. The sample size of herds for each productive region was based on an estimated expected herd prevalence of 5\%, from values reported by Belchior et al. (2016) in Minas Gerais, with a 95\% confidence level and an absolute error $(d)$ of $3 \%$ (THRUSFIELD, 2007). These parameters give a sample size 203 herds in each region. For regions where it was not possible to achieve this number of samples, at least 150 herds were sampled to ensure that the absolute error would not exceed $3.5 \%$, with a confidence level of $95 \%$.

Figure 1. Paraná State, showing divisions into sampling/production regions.

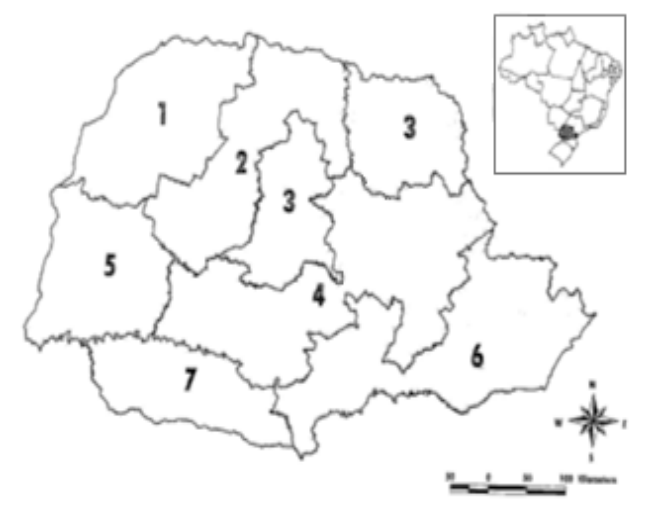

Caption:

1-Northwest

2-Center-West-North

3-North Frontier

4-Center-South

5- West

6-East-South

7-Southeast

The distribution of sampling units within each region was performed in two stages (SALMAN, 2003). In the first stage, farms or primary sampling units were randomly selected. In the second stage, breeding bovine or buffalo over 24 months of age were selected by systematic random sampling. In this subpopulation, females within 15 days of birth or abortion were excluded from the study in order to 
avoid animals that may be unresponsive to the test, as recommended by the PNCEBT (BRASIL, 2006).

In each selected herd, the number of animals tested aimed at achieving a 90\% sensitivity and specificity at the herd level. The number of animals sampled depended on the number of eligible cattle in the herd. The cut-off point of number of positive animals required to classify the herd as positive was simulated (MARTIN et al., 1992; DONALD et al., 1994; SALMAN, 2003) using Epi Tools - HerdPlus software. Simulations were conducted for different herd sizes to obtain the sample size and cut-off points, as shown in Table 1.

Table 1. Number of adult females, number of animals to be sampled, and minimum number of positive animals required to classify a herd as positive.

\begin{tabular}{ccc}
\hline Number of cows $\geq \mathbf{2 4} \mathbf{~ m}$. & Number of cows to be tested & $\begin{array}{c}\text { Cut-off point } \\
\text { (No of positive animals) }\end{array}$ \\
\hline 1 to 99 & 20 & 1 \\
100 or more & 40 & 2 \\
\hline
\end{tabular}

The intradermal comparative cervical tuberculin test (CCT) was used, assuming a sensitivity and specificity of $80 \%$ and $99.5 \%$, respectively, in accordance with Lôbo (2008). Animals classified as inconclusive based on test findings were retested after 60 days. Those with repeated inconclusive results were reclassified as positive. The interpretation of the CCT followed PNCEBT standards (BRASIL, 2006).

During the first visit to each herd, the study objectives were explained to the producer, who signed a commitment authorizing the disposal (by culling or destruction on site) of all positive animals. The producer was compensated for the slaughtered animals. The randomly selected cattle were individually identified, trichotomized in the middle third of the left cervical region at the sites of the CCT application, and inoculated as recommended by the PNCEBT (BRASIL, 2006). After $72 \pm 6$ hours, the test readout and interpretation were performed.

A questionnaire was applied to collect data for the investigation of risk factors. The questions were related to the productive characteristics of the sampled herds, general production practices, and health management, as well as some aspects of public health interest, as described below:

a) Type of production-categories: "beef cattle," "dairy cattle," or "dual-purpose herds." Beef herds were classified according to the main production purposes of breeding, rearing, and fattening; both full and partial production cycles were considered. The main goal was fattening and slaughter of animals for meat production. In these properties, the presence of dairy cattle for on-farm milk consumption did not prevent the herd from being characterized as beef type.

Herds classified as dairy cattle were those whose main activities were milk production, regardless of the destination of the milk produced-consumption, sale, or processing. In the dual-purpose category, the herds included were dedicated to both meat production, in full or partial cycle of breeding, rearing, and fattening, and to dairy activity. In this category, the beef cattle and dairy cattle shared environments and facilities.

In herds classified as dairy or dual-purpose, the number of milkings performed each day was recorded as "no milking," "one milking per day," or "two milkings per day." The method of milking was 
recorded as "manual milking," "mechanical milking with bucket," or "mechanical milking in parlor."

b) Farming type-categories: "confined," "semiconfined," or "extensive." The herds under the category "confined" were those in which the animals were raised and fed in a systematic and controlled manner, and in limited and small spaces. "Semiconfined" indicated that the herds were raised on pastures, and were provided with supplemental feeding throughout or for part of the year. In herds of the "extensive" category, the animals were raised exclusively on pastures, and were optionally provided with protein concentrate and/or mineral salt.

c) Herd size-Population of cattle on the properties were categorized as: "castrated males," "males between 0 and 6 months," "males between 6 and 12 months," "males between 12 and 24 months," "males over 24 months," "females between 0 and 6 months," "females between 6 and 12 months," "females between 12 and 24 months," and "females over 24 months."

d) Existence of other domestic species on the property-options: "equine," "swine," and "poultry."

e) Existence of free-living wild species on the property-options: "cervids," "capybaras," "marsupials," "wild felines," and "wild primates."

f) Dichotomous variables-options "yes" or "no": "TB test required before purchasing animals," "pasture rental at any time of the year," "common pastures with other properties," "acquisition of females or males for reproduction," "sale of females or males for reproduction," "sharing of water sources or troughs with other properties," "sharing inputs with other properties," "sharing equipment with other properties," "sharing of employees with other properties" and "existence of flooded areas in the property".

Estimates of the herd-level and animal-level prevalence were performed using STATA ${ }^{\circledR}$ software version 12. As a simple random sample of herds was performed within each region, the estimated herd prevalence was based on the ratio between herds classified as positive in the sample and the total sampled herds in the region. To estimate herd prevalence at the state level, it was necessary to consider that the sampling was not proportional to the number of herds in each region; therefore, samples from each region had different weights in the calculation of state prevalence.

According to Dohoo et al. (2010), the most common method of obtaining sample weights is to use the inverse of the sample selection probability. The results reflect the number of individuals in the population that each individual in the sample represents. Thus, for the calculation of herd prevalence at the state level, a weighting with the weight $\mathrm{P}_{1}$ was applied to each sampled herd/ property in each region:

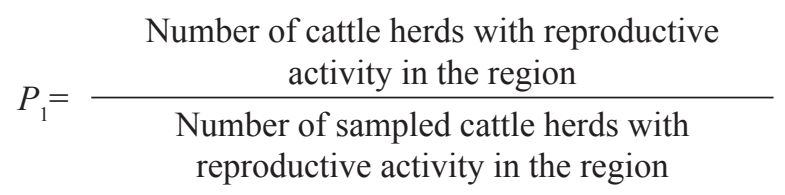

To estimate the prevalence of TB in cows aged 24 months or older, the cluster sampling conducted in two stages was considered. The clusters were the herds within which cows aged 24 months or older were sampled. Thus, to calculate the state prevalence of these animals, a weighting was performed with $\mathrm{P}_{2}$ considered as the weight of each cow aged 24 months or older sampled in relation to its herd and to the respective region:

$$
\begin{gathered}
P_{2}=\frac{\text { cows } \geq 24 \text { months in the herd }}{\text { cows } \geq 24 \text { months sampled in the herd }} \mathrm{X} \\
\frac{\text { cows } \geq 24 \text { months in the region }}{\text { cows } \geq 24 \text { months sampled in the region }}
\end{gathered}
$$

The prevalence calculations were performed using STATA ${ }^{\circledR}$ software, version 12 (module: 
Statistics $\rightarrow$ Summaries, tables, and tests $\rightarrow$ Proportion). The prevalence in adult cows considered a multistage sampling ([aba]: SE/Cluster $\rightarrow$ Survey data estimation $\rightarrow$ Survey settings $\rightarrow$ Number of stages $\rightarrow 2$ : first stage, properties, second stage, cows aged 24 months or older). The confidence intervals (CIs) of the herd prevalence in each region were obtained using the Exact Binomial Distribution (module: Statistics $\rightarrow$ Summaries, tables, and tests $\rightarrow$ Confidence Intervals).

The putative risk factors were identified using the Chi-square univariable analysis (PETRIE; WATSON, 2009). Variables with $p$-value $\leq 0.20$ were selected for the multiple logistic regression model using the hierarchical backward elimination procedure. The final model included only those variables with $\mathrm{p} \leq 0.05$. The variable "stratum/ region" was included in the logistic model as a control variable in order to analyze the association of possible risk factors with the presence of tuberculosis, regardless of the region in which the herds were located. STATA MP $12 \circledR$ software was used for these calculations.
To evaluate the discriminatory performance of the variables included in the final logistic model, the receiver operating characteristic (ROC) curve was calculated to assess the predictive capacity of the model. The specific function of STATA MP $12 \AA$ was used for this calculation.

\section{Results}

Sample profile

Figure 2 shows the distribution of sampled herds throughout Paraná. The responses to the questionnaire completed during the farm visits indicated that Paraná was primarily characterized by small cattle herds dedicated to extensive grazing dairy farming $(41.1 \%)$ or mixed, dual-purpose, livestock production (42.2\%). Only $21.7 \%$ of the herds had some degree of confinement, and $16.7 \%$ were classified as beef cattle. Only $25 \%$ of the farms possessed more than 22 animals of at least 24 months of age. Rented pastures or shared areas between neighboring farms were not very common, reported in only $10 \%$ of the sampled farms.

Figure 2. Location of Paraná within Brazil and spatial distribution of sample herds.

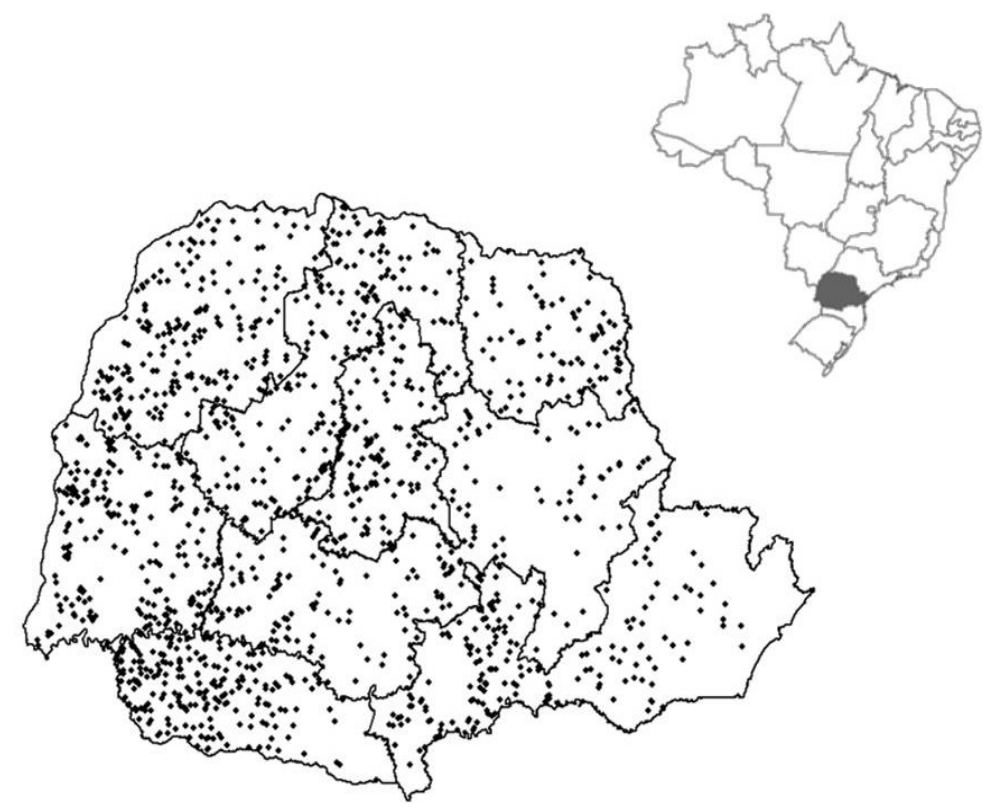


The dairy farms sampled can be characterized as intensive for Brazilian standards. Approximately $50 \%$ of the dairy farms held pure European breeds. More than $60 \%$ of the farms milked more than once per day, $40.7 \%$ had mechanical milking, and $65 \%$ refrigerated the milk; of these, $86.4 \%$ cooled milk in their own tanks. The frequency of the use of artificial insemination in these farms $(40 \%)$ was greater than in the rest of the herds (around 15\%). The average milk production was $133.6 \mathrm{~L} /$ day (standard deviation $=504.16$ ), and $75 \%$ of the farms produced up to $125 \mathrm{~L} /$ day, with up to 14 lactating cows.

Analysis of the health prevention practices revealed that only $23 \%$ of the farms reported performing diagnostic tests for bovine tuberculosis. In more than $40 \%$ of these farms, the tests were performed when cattle were purchased or when required for movement or other purposes, such as auctions. Veterinary assistance was present in 34\% of farms and care was provided by veterinarians from cooperatives in $23 \%$ of cases.

As for trade and animal consumption and sale of by-products, approximately $44 \%$ of the farms from Paraná reported buying animals, but only $23 \%$ of these required health certificates and diagnostic tests for tuberculosis at the time of purchase. Animals were slaughtered at the end of their reproductive lives in approximately $72 \%$ of the farms, but in just above $50 \%$ of these cases, animals were destined to slaughter plants with veterinary inspection; the other farms reported slaughtering animals on the premises $(32 \%)$ or in unregistered slaughterhouses $(18 \%)$.

The production of milk derivatives, such as milk and butter, was for internal consumption in $90 \%$ of farms, without undergoing any kind of official health control. The habit of drinking raw milk was observed in $15 \%$ of the farms. The delivery of milk in bulk was a routine practice in $40 \%$ of the State farms.

\section{Prevalence of herds and animals}

A total of 1,419 herds and 16,045 animals were sampled; of these animals, 220 were submitted for retesting following inconclusive results in the first test. Among the retested animals, 13 were classified as positive in accordance with the PNCEBT recommendations (BRASIL, 2006). Tables 2 and 3 display the existing number of herds and of bovine females over 24 months of age, the numbers sampled per region, and the estimated prevalence infected herds and animals with bovine tuberculosis. The prevalence of herds infected with bovine tuberculosis in the state of Paraná was $2.25 \%$ [95\% CI: $1.31 \%-3.00 \%$ ], while the prevalence of positive animals for the tuberculin test was estimated at $0.42 \%$ [95\% CI: $0.04 \%$ $0.81 \%$ ].

The comparison of estimated frequencies per region revealed that the northwest, center-westnorth, and center-south regions had higher mean herd prevalence than those of the other regions. However, it was not possible to conclude with $95 \%$ of confidence that the estimated prevalence differed significantly between the seven regions. Only the west region showed no positive animals, which suggests the presence of residual disease levels in this part of the state.

The sample included 1,217 farms with herds having up to 99 animals aged above 24 months, as well as 202 farms with herds containing 100 or more animals in this age category. Following the criteria for classifying a herd as positive, presented in Table 1, only one herd with more than 99 animals aged 24 months or more was classified as negative, despite having one single animal that tested positive. 
Table 2. Census data and herd prevalence per region and for the state of Paraná.

\begin{tabular}{|c|c|c|c|c|c|c|}
\hline \multirow{2}{*}{\multicolumn{2}{|c|}{ Stratum/Region }} & \multirow{2}{*}{$\begin{array}{c}\text { Herds } \\
\text { with adult } \\
\text { breeding cattle }\end{array}$} & \multicolumn{2}{|c|}{ Herds } & \multirow{2}{*}{$\begin{array}{c}\text { Apparent } \\
\text { Prevalence (\%) }\end{array}$} & \multirow[b]{2}{*}{ CI $(95 \%)$} \\
\hline & & & Tested & Positive & & \\
\hline $1-$ & Northwest & 22.596 & 217 & 8 & 3.69 & [1.60-7.13] \\
\hline $2-$ & Center-West-North & 19.677 & 201 & 7 & 3.48 & [1.41-7.04] \\
\hline $3-$ & North Frontier & 33.369 & 204 & 4 & 1.96 & [0.54-4.94] \\
\hline & Center-South & 38.816 & 180 & 7 & 3.89 & [1.58-7.85] \\
\hline & West & 31.652 & 200 & 0 & 0.00 & {$[0.00-1.83]$} \\
\hline & East-South & 27.741 & 194 & 2 & 1.03 & {$\left[\begin{array}{lll}0.12 & -3.67\end{array}\right]$} \\
\hline & Southeast & 43.538 & 223 & 5 & 2.24 & {$[0.73-5.15]$} \\
\hline Sta & & 217.389 & 1,419 & 33 & 2.15 & [1.31-3.00] \\
\hline
\end{tabular}

CI: Confidence Interval

Source: Paraná (2008).

Table 3. Census data and animal prevalence per region and for the state of Paraná.

\begin{tabular}{|c|c|c|c|c|c|c|}
\hline \multirow[b]{2}{*}{ Stratum/Region } & \multirow{2}{*}{$\begin{array}{c}\text { Cows } \geq 24 \\
\text { months in the } \\
\text { region * }\end{array}$} & \multirow{2}{*}{$\begin{array}{c}\text { Cows } \geq 24 \\
\text { months in the } \\
\text { herds sampled * }\end{array}$} & \multicolumn{2}{|c|}{ Cows $\geq 24$ months } & \multirow{2}{*}{$\begin{array}{c}\text { Apparent } \\
\text { Prevalence } \\
(\%)\end{array}$} & \multirow[b]{2}{*}{ CI $(95 \%)$} \\
\hline & & & Tested & Positive & & \\
\hline 1 - Northwest & $1,187,829$ & 11,572 & 3,361 & 15 & 1.08 & {$[0.00-2.59]$} \\
\hline 2 - Center-West-North & 627,789 & 9,031 & 3,009 & 16 & 0.43 & {$[0.00-0.87]$} \\
\hline 3 - North Frontier & $1.042,209$ & 5,750 & 2,274 & 10 & 0.17 & {$[0.00-0.40]$} \\
\hline 4 - Center-South & 938,947 & 7,466 & 2,177 & 14 & 0.29 & {$[0.01-0.57]$} \\
\hline 5 - West & 548,059 & 3,963 & 1,758 & 0 & 0 & {$[0.00-0.00]$} \\
\hline 6 - East -South & 221,562 & 2,171 & 1,224 & 3 & 0.20 & {$[0.00-0.54]$} \\
\hline 7 - Southwest & 567,757 & 3,629 & 2,242 & 5 & 0.22 & [0.01- 0.43$]$ \\
\hline State & $5.134,4152$ & 43,582 & 16,045 & 63 & 0.42 & {$[0.04-0.81]$} \\
\hline
\end{tabular}

CI: Confidence interval.

Source: Paraná (2008).

\section{Univariable analysis}

Table 4 presents the results of the univariable analysis, showing only the variables with epidemiological importance for the study or those with p-values below 0.2 in the chi-square test. Some qualitative variables were re-grouped. Disease prevalence was higher in dairy breeding operations $(3.27 \%)$ compared to mixed $(1.69 \%)$ or beef breeding (1.26\%) farms. Mechanical milking was associated with a higher prevalence of bovine tuberculosis, regardless of its use in a portable device or a milking parlour.
The cut-off point used to categorize the variable "number of cows aged over 24 months" was the value of the third quartile - 22 bovine females over 24 months of age. The frequencies of farms affected by bovine tuberculosis in the three first quartiles were equivalent; all were very small farms with similar productive practices. Larger farms had higher risk of being positive; this category was heterogeneous and contained herds that ranged from 23 to 950 adult animals, but we did not further split it in order to avoid losing analytical power given the small number of positive herds. 
Table 4. Results of univariable analysis for screening possible herd-level risk factors for bovine tuberculosis in Paraná state.

\begin{tabular}{lccc}
\hline \multicolumn{1}{c}{ Variable } & Exposed/Positives & Exposed/Positives & p value \\
\hline Type of operation: & & & \\
. Dairy & $19 / 32$ & $562 / 1379$ & 0.034 \\
. Beef or Mixed & $13 / 32$ & $817 / 1379$ & \\
Bovine breed: & $14 / 33$ & $326 / 1374$ & 0.013 \\
. European dairy breeds & $19 / 33$ & $1048 / 1374$ & \\
. Other breeds & & & \\
Type of production system: & $23 / 33$ & $1084 / 1381$ & 0.226 \\
. Extensive & $10 / 33$ & $297 / 1381$ & \\
. Confined or semi-confined & & & \\
Type of milking: & $18 / 33$ & $270 / 1374$ & 0.000 \\
. Mechanical & $15 / 33$ & $1104 / 1374$ & \\
. Manual or no milking & & & \\
Rents pasture: & $6 / 32$ & $132 / 1380$ & 0.084 \\
Yes & $26 / 32$ & $1248 / 1380$ & \\
. No & & & \\
Purchased animals: & $21 / 33$ & $596 / 1379$ & 0.019 \\
. Yes & $12 / 33$ & $783 / 1379$ & \\
. No & & & 0.000 \\
Bovine herd $\geq 24 m:$ & $14 / 33$ & $330 / 1386$ & \\
. $\leq 22$ animals & $19 / 33$ & & \\
. $>22$ animals & & & \\
\hline
\end{tabular}

\section{Multiple logistic regression}

Variables with $p$-value $\leq 0.20$ in the univariable analysis were selected for the multiple logistic regression model. This followed a hierarchical backward elimination procedure and the final reduced model only included variables with $\mathrm{p}<$
0.05. Table 5 shows that herds with more than 22 cows over 24 months of age $(25 \%$ of the total sampled farms) had an odds of approximately 2.4 compared to smaller herds. The odds ratio was 5.18 for herds with mechanical milking, compared to farms that did not milk or whose herds were milked manually.

Table 5. Multiple logistic regression model of risk factors (odds ratios) for tuberculosis in herds with reproductive activity in Paraná state, Brazil.

\begin{tabular}{lccc}
\hline \multicolumn{1}{c}{ Variable } & Odds Ratio & CI (95\%) & p \\
\hline $\begin{array}{l}\text { Size of adult female herd }(\text { cows }>24 \mathrm{~m}): \\
.>22 \text { cows }\end{array}$ & 2.40 & {$[1.11-5.19]$} & 0.026 \\
$\begin{array}{l}\text { Type of milking: } \\
\text {. Mechanical milking }\end{array}$ & 5.18 & {$[2.45-10.95]$} & 0.000 \\
\hline
\end{tabular}

CI: Confidence Interval.

Pseudo $\mathrm{R}^{2}=0.1137$ with 1,209 observations. 
The discriminatory performance of variables in the final logistic model was measured by receiver operating characteristic (ROC) curve analysis, as shown in Figure 3. The area under the ROC curve indicates the ability of the model to predict the proportion of positive and negative herds. The obtained value of 0.743 suggests a good discrimination between positive and negative herds, which should ideally fall between 0.8 and 0.9 (KLEINBAUM; KLEIN, 2010).

Figure 3. ROC curve of the multiple logistic regression model.

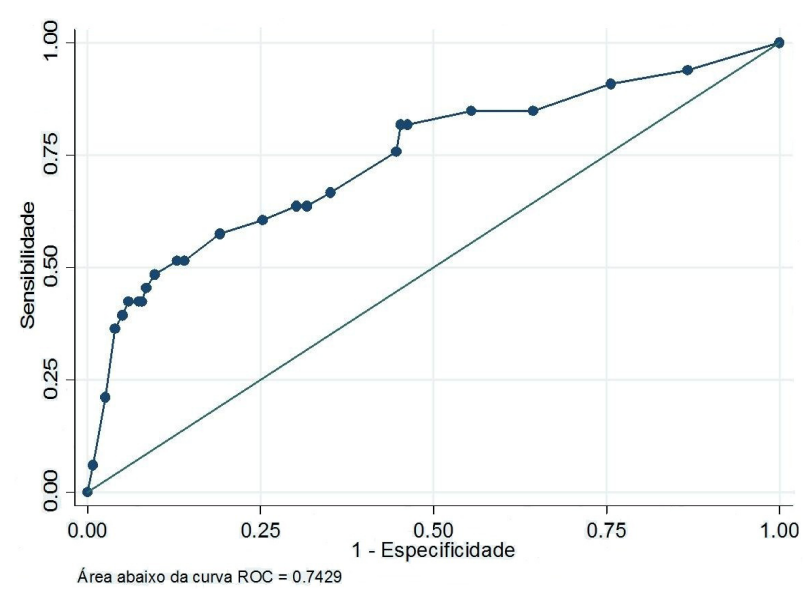

XX: 1-Specificity; YY Sensitivity

Area under the ROC curve $=0.7429$

\section{Discussion}

The prevalence of herds with bovine tuberculosis in the state of Paraná was $2.25 \%$ [95\% CI: $1.31 \%-3.00 \%$ ], which is below what has been found in Minas Gerais, Espírito Santo, and São Paulo, close to prevalence estimates reported in Bahia, Pernambuco, Rondônia, Mato Grosso do Sul, Mato Grosso, Goiás, Federal District, and Rio Grande do Sul, but higher than herd prevalence in Santa Catarina (BAHIENSE et al., 2016; BARBIERI et al., 2016; DIAS et al., 2016; GALVIS et al., 2016; GUEDES et al., 2016; LIMA et al., 2016; NÉSPOLI et al., 2016; QUEIROZ et al., 2016; RIBEIRO et al., 2016; ROCHA et al., 2016; BAUMGARTEN et al., 2016; VENDRAME et al., 2016).

The estimated prevalence revealed that the northwest, central-west-north, and center-south regions had higher prevalence of farms compared to the other regions. However, it was not possible to state with $95 \%$ of confidence that the estimated prevalence in the seven regions differed significantly. Only the west region had no positive animals, which may suggest residual disease in this part of the state.

Intensive dairy farms, where mechanical milking is practiced, had a higher chance of being positive for bovine tuberculosis. Lilenbaum et al. (1998), Belchior et al. (2016) and Brasil (2006) also reported higher risk for dairy herds, as the intensiveness of production and confinement may contribute to the maintenance of the disease (PEREZ et al., 2002). In this study, approximately $80 \%$ of the milk producers that used mechanical milking systems supplied milk directly to dairy industries and more than $85 \%$ milked animals at least twice per day. Farms that performed manual milking accounted for approximately $30 \%$ of the cases. This result is of strategic importance for the PNCEBT.

The type of intensive or semi-confined breeding mentioned as a risk factor by Humblet et al. (2009), and Reilly and Courtney (2007) was not associated with an increased likelihood of bovine tuberculosis infection in the current study $(p=0.416)$. This can be explained by the fact that the majority (79\%) of the farms sampled were classified as extensive, which makes this variable less able to discriminate between the types of production and management associated with the presence of tuberculosis in the state of Paraná. However, the practice of mechanical milking is an indirect indicator of intensive and mechanized dairy farming, which confirms the observations of the above-mentioned authors. 
The analytical model revealed that larger farms with more than 22 adult animals (the third quartile of adult herd size) had higher risk of infection by Mycobacterium bovis. The number of animals appears to be small, but reflects the demographic structure of the Paraná herd. Larger herds were also identified as a risk factor by Oliveira et al. (2008) in a retrospective study conducted in Rio de Janeiro, with data from 1959 to 1989, as well as by BrooksPollock and Kelling (2009).

It is important to emphasize that the risk variables identified in this study are not necessarily causal factors but are rather productive characteristics that better and more objectively reflect production systems and intensive management. These situations provide increased opportunity for contact between infected and susceptible animals, thus increasing the risk of disease transmission (HUMBLET et al., 2009; BELCHIOR et al., 2016; ELIAS et al., 2008; PEREZ et al., 2002).

Although the prevalence is low in smaller farms and those with low incorporation of production technology, current practices that pose a risk to public health, such as the consumption of unpasteurized milk and its by-products and the slaughter of culled animals in places without sanitary controls, require that this segment of the farming community be also included in sanitary education programs.

\section{Conclusions}

The prevalence of bovine tuberculosis is low in Paraná, albeit with a heterogeneous epidemiological situation throughout the state. The combination of low prevalence with risk factors associated to larger herds and more intensive dairy farming, renders the state of Paraná a good candidate for the implementation of industry-based freeherd accreditation schemes and makes a case for planning risk-based surveillance targeted at major dairy basins.

\section{Acknowledgements}

The authors acknowledge the logistical and financial support from MAPA, ADAPAR, CNPq and FAPESP.

\section{References}

ALFINITO, J. W.; OLIVEIRA, F. R. Estudo epidemiológico da tuberculose bovina na Ilha de Marajó. In: CONGRESSO BRASILEIRO DE MEDICINA VETERINÁRIA, 20., 1986, Cuiabá. Anais... Cuiabá: Sociedade Matogrossense de Medicina Veterinária, 1986. p. 216-217.

BAHIENSE, L.; ÁVILA, L. N. de; BAVIA, M. E.; AMAKU, M.; DIAS, R. A.; GRISI-FILHO, J. H. H.; FERREIRA, F.; TELLES, E. O.; GONÇALVES, V. S. P.; HEINEMANN, M. B.; FERREIRA NETO, J. S. Prevalence and risk factors for bovine tuberculosis in the State of Bahia, Brazil. Semina: Ciências Agrárias, Londrina, v. 37, n. 5, p. 3549-3560, 2016. Suplemento 2.

BARBIERI, J. M.; OLIVEIRA, L. F.; DORNELES, E. M. S.; MOTA, A. L. A. A.; GONÇALVES, V. S. P.; MALUF, P. P.; FERREIRA NETO, J. S.; FERREIRA, F.; DIAS, R. A.; TELLES, E. O.; GRISI-FILHO, J. H. H.; HEINEMANN, M. B.; AMAKU, M.; LAGE, A. P. Epidemiological status of bovine tuberculosis in the state of Minas Gerais, Brazil. Semina: Ciências Agrárias, Londrina, v. 37, n. 5, p. 3531-3548, 2016. Suplemento 2.

BELCHIOR, A. P. C.; LOPES, L. B.; GONÇALVES, V. S. P.; LEITE, R. C. Prevalence and risk factors for bovine tuberculosis in Minas Gerais State, Brazil. Tropical Animal Health and Production, Edinburg, v. 48, n. 2, p. 373-378, 2016.

BRASIL. Ministério da Agricultura e do Abastecimento. Programa Nacional de Controle e Erradicação da Brucelose e da Tuberculose Animal (PNCEBT). Brasília: MAPA/SDA/DSA, 2006.

BROOKS-POLLOCK, E.; KEELING, M. Herd size and bovine tuberculosis persistence in cattle farms in Great Britain. Preventive Veterinary Medicine, Amsterdam, v. 92, n. 4, p. 360-365, 2009.

CASTRO, D. Prevalência de bovinos reagentes à prova tuberculínica no Município de Uberaba, MG, 1978. 1979. Dissertação (Mestrado em Medicina Veterinária Preventiva) - Escola de Veterinária, Universidade Federal de Minas Gerais, Belo Horizonte. 
DIAS, R. A.; STANOJLOVIC, F. M. U.; BELCHIOR, A. P. C.; FERREIRA, R. S.; GONÇALVES, R. C.; AGUIAR, R. S. C. B.; SOUSA, P. R.; SANTOS, A. M. A.; AMAKU, M.; FERREIRA, F.; TELLES, E. O.; GRISI-FILHO, J. H. H.; GONÇALVES, V. S. P.; HEINEMANN, M. B.; FERREIRA NETO, J. S. Prevalence and risk factors for bovine tuberculosis in the state of São Paulo, Brazil. Semina: Ciências Agrárias, Londrina, v. 37, n. 5, p. 3673-3684, 2016. Suplemento 2.

DOHOO, I.; MARTIN, W.; STRYHN, H. Veterinary epidemiologic research. $2^{\text {th }}$ ed. Charlottetown: Prince Edward Island: AVC, 2010. 867 p.

DONALD, A. W.; GARDNER, I. A.; WINGGINS, A. D. Cut-off points for aggregate herd testing in the presence of disease clustering and correlation of test errors. Preventive Veterinary Medicine, Amsterdam, v. 19, n. 3/4, p. 167-187, 1994.

EPI TOOLS - HerdPlus Utilities. AusVet, 2016. Disponível em: <http://epitools.ausvet.com.au/content. php?page $=$ HerdPlus $>$. Acesso em: 10 out. 2016.

ELIAS, K.; HUSSEIN, D.; ASSEGED, B.; WONDWOSSEN, T.; GEBEYEHU, M. Status of bovine tuberculosis in Addis Ababa dairy farms. Revue Scientifique et Technique de l'Office Internacional des Epizooties, Paris, v. 27, n. 3, p. 915-923, 2008.

FEDERAÇÃO DA AGRICULTURA DO ESTADO DO PARANÁ - FAEP. Plano Diretor para o agronegócio do Paraná. Curitiba: [s.n.], jun. 2010.

GALVIS, J. O. A.; GRISI-FILHO, J. H. H; COSTA, D.; SAID, A. L. P. R.; AMAKU, M.; DIAS, R. A.; FERREIRA, F.; GONÇALVES, V. S. P.; HEINEMANN, M. B.; TELLES, E. O.; FERREIRA NETO, J. S. Epidemiologic characterization of bovine tuberculosis in the state of Espírito Santo, Brazil. Semina: Ciências Agrárias, Londrina, v. 37, n. 5, p. 3567-3578, 2016. Suplemento 2.

GUEDES, I. B.; BOTTENE, I. F. N.; MONTEIRO, L. A. R. C.; LEAL FILHO, J. M.; HEINEMANN, M. B.; AMAKU, M.; GRISI-FILHO, J. H. H.; DIAS, R. A.; FERREIRA, F.; TELLES, E. O.; GONÇALVES, V. S. P.; FERREIRA NETO, J. S. Prevalence and risk factors for bovine tuberculosis in the state of Mato Grosso do Sul, Brazil. Semina: Ciências Agrárias, Londrina, v. 37, n. 5, p. 3579-3588, 2016. Suplemento 2.

HUMBLET, M. F.; BOSCHIROLI, M. L.; SAEGERMAN, C. Classification of worldwide bovine tuberculosis risk factors in cattle: a stratified approach. Veterinary Research, Les Ulis, v. 40, n. 5, p. 1-24 2009.

KLEINBAUM, D. G.; KLEIN, M. Logistic regression: a self-learning text. $3^{\text {th }}$ ed. New York: Springer-Verlag, 2010. 702 p.
LAENDER, F. C. Prevalência de bovinos reagentes à prova de tuberculina no município de Pedro Leopoldo, $M G$, 1977. 1978. Dissertação (Mestrado em Medicina Veterinária Preventiva) - Escola de Veterinária, Universidade Federal de Minas Gerais, Belo Horizonte.

LILENBAUM, W.; SCHETTINI, J.; RIBEIRO, E. R.; SOUZA. G. N.; MOREIRA, E. C.; FONSECA, L. S. Tuberculose bovina. Prevalência e estudo epidemiológico em treze propriedades de diferentes sistemas de produção na região dos lagos do Estado do Rio de Janeiro. Revista Brasileira de Medicina Veterinária, Rio de Janeiro, v. 20, p. 120-123, 1998.

LIMA, P. B.; NASCIMENTO, D. L.; ALMEIDA, E. C.; PONTUAL, K. A. Q.; AMAKU, M.; DIAS, R. A.; FERREIRA, F.; GONÇALVES, V. S. P.; TELLES, E. O.; GRISI-FILHO, J. H. H.; HEINEMANN, M. B.; SILVA, J. C. R.; FERREIRA NETO, J. S. Epidemiological situation of bovine tuberculosis in the state of Pernambuco, Brazil. Semina: Ciências Agrárias, Londrina, v. 37, n. 5, p. 3601-3610, 2016. Suplemento 2.

LÔBO, J. R. Análise custo-benefício da certificação de propriedades livres de tuberculose bovina. 2008. Dissertação (Mestrado em Medicina Veterinária) Faculdade de Agronomia e Medicina Veterinária, Universidade de Brasília, Brasília.

MARTIN, S. W.; SHOUKRI, M.; THORBUM, M. A. Evaluating the health status of herds based on tests applied to individuals. Preventive Veterinary Medicine, Amsterdam, v. 14, n. 1-2, p. 33-43, 1992.

NÉSPOLI, J. M. B.; NEGREIROS, R. L.; AMAKU, M.; DIAS, R. A.; FERREIRA, F.; TELLES, E. O.; HEINEMANN, M. B.; GRISI-FILHO, J. H. H.; GONÇALVES, V. S. P.; FERREIRA NETO, J. S. Epidemiological situation of bovine tuberculosis in the state of Mato Grosso, Brazil. Semina: Ciências Agrárias, Londrina, v. 37, n. 5, p. 3589-3600, 2016. Suplemento 2.

OLIVEIRA, I. A. S.; MELO, H. P. C.; CAMARA, A.; DIAS, R. V. C.; SOTO-BLANCO, B. Prevalência de tuberculose no rebanho bovino de Mossoró, Rio Grande do Norte. Brazilian Journal of Veterinary Research and Animal Science, São Paulo, v. 44, n. 6, p. 395-400, 2007.

OLIVEIRA, V. M.; FONSECA, A. H.; PEREIRA; M. J. S.; CARNEIRO, A. V.; JESUS, V. L. T. ALVES, P. A. M. Análise retrospectiva dos fatores associados à distribuição da tuberculose bovina no estado do Rio de Janeiro. Arquivo Brasileiro de Medicina Veterinária e Zootecnia, Belo Horizonte, v. 60, n. 3, p. 574-579, 2008.

PARANÁ. Secretaria de Estado da Agricultura e do Abastecimento. Informe de vacinação contra febre aftosa. Curitiba: [s.n.], 2012. 
PEREZ, A. M.; WARD, M. P.; CHARMANDARIAN, A.; RITACCO, V. Simulation model of within-herd transmission of bovine tuberculosis in Argentine dairy herds. Preventive Veterinary Medicine, Amsterdam, v. 54, n. 2002, p. 361-372, 2002.

PETRIE, A.; WATSON, P. Estatística em ciência animal e veterinária. $2^{\text {th }}$ ed. São Paulo: Roca, 2009. 236 p.

POLETTO, R.; KREUTZ, L. C.; GONZALES, J. C. AND BARCELLOS, L. J. G. Prevalência de tuberculose, brucelose e infecção víricas em bovinos leiteiros do município de Passo Fundo, RS. Ciência Rural, Santa Maria v. 34, n. 2, p. 595-598, mar/abr. 2004.

QUEIROZ, M. R.; GROFF, A. C. M.; SILVA, N. S.; GRISI-FILHO, J. H. H.; AMAKU, M.; DIAS, R. A.; TELLES, E. O.; HEINEMANN, M. B.; FERREIRA NETO, J. S.; GONÇALVES, V. S. P. FERREIRA, F. Epidemiological status of bovine tuberculosis in the state of Rio Grande do Sul, Brazil. Semina: Ciências Agrárias, Londrina, v. 37, n. 5, p. 3647-3658, 2016. Suplemento 2.

REILLY, L. A.; COURTENAY, O. Husbandry practices, badger sett density and habitat composition as risk factors for transient and persistent bovine tuberculosis on UK cattle farms. Preventive Veterinary Medicine, Amsterdam, v. 80, n. 2/3, p. 129-142, 2007.

RIBEIRO, L. A.; GONÇALVES, V. S. P.; FRANCISCO, P. F. C.; MOTA, A. L. A. A.; NASCIMENTO, G. T.; LICURGO, J. B.; FERREIRA, F.; GRISI-FILHO, J. H. H.; FERREIRA NETO, J. S.; AMAKU, M.; DIAS, R. A.; TELLES, E. O.; HEINEMANN, M. B.; BORGES, J. R. J. Epidemiological status of bovine tuberculosis in the Federal District of Brazil. Semina: Ciências Agrárias, Londrina, v. 37, n. 5, p. 3561-3566, 2016. Suplemento 2.
ROCHA, W. V.; JAYME, V. S.; MOTA, A. L. A. A.; BRITO, W. M. E. D; PIRES, G. R. C; GRISI-FILHO, J. H. H; DIAS, R. A.; AMAKU, M.; TELLES, E. O.; HEINEMANN, M. B.; FERREIRA, F.; FERREIRA NETO, J. S.; GONÇALVES, V. S. P.; Prevalence and herd-level risk factors of bovine tuberculosis in the State of Goiás, Brazil. Semina: Ciências Agrárias, Londrina, v. 37, n. 5, p. 3625-3628, 2016. Suplemento 2.

SALMAN, M. D. Animal disease surveillance and survey systems methods and applications. Iowa: WileyBlackwell, 2003. 222 p.

STATA MP 12. Data analysis and statistical software. (C) Copyright 1996-2011. StataCorp LP. [S.1.: s.n.].

THRUSFIELD, M. Veterinary epidemiology. $3^{\text {th }}$ ed. Oxford: Blackwell Science, 2007. 610 p.

VELOSO, F. P.; BAUMGARTEN, K. D.; MOTA, A. L. A. A.; FERREIRA, F.; FERREIRA NETO, J. S.; GRISI-FILHO, J. H. H.; DIAS, R. A.; AMAKU, M.; TELLES, E. O.; HEINEMANN, M. B.; GONÇALVES, V. S. P. Prevalence and herd-level risk factors of bovine tuberculosis in the State of Santa Catarina, Brazil. Semina: Ciências Agrárias, Londrina, v. 37, n. 5, p. 3659-3672, 2016. Suplemento 2.

VENDRAME, F. B.; AMAKU, M.; FERREIRA, F.; TELLES, E. O.; GRISI-FILHO, J. H. H.; GONÇALVES, V. S. P.; HEINEMANN, M. B.; FERREIRA NETO, J. S.; DIAS, R. A. Epidemiologic characterization of bovine tuberculosis in the State of Rondônia, Brazil. Semina: Ciências Agrárias, Londrina, v. 37, n. 5, p. 3639-3646, 2016. Suplemento 2. 
